\title{
IDENTIFIKASI FAKTOR PENENTU MINAT BELI PADA PRODUK KECANTIKAN HIJAU
}

\author{
Jessy Wijaya Kusuma ${ }^{1}$, Jul Aidil Fadli² \\ Fakultas Ekonomi dan Bisnis Universitas Esa Unggul \\ Jalan Arjuna Utara No 9 Kebon Jeruk Jakarta 11510 \\ jul.fadli@esaunggul.ac.id
}

\begin{abstract}
This study conducted to identify the effect of green product and green brand image on green purchase intention in beauty products. The Environmental issues accompanied by various campaigns and government instructions in the management of environmental damage encourage consumer and producer preferences to consume and produce products with environmentally friendly concepts. The limitations of the research and the contradictions of previous studies prompted the author to investigate the effect of green products, green brand image and green purchase intention in the current growing green marketing trend in Indonesia. The data used are primary data with a questionnaire collected from 120 respondents in Jabodetabek. The sampling technique used a nonprobability sampling method with purposive sampling technique with the sample criteria being women aged 18 years, who know and like beauty care products related to the green product. The results show that green product and green brand image will jointly influence the green purchase intention in green marketing efforts. Meanwhile, the relationship between green product and green purchase intention needs to be mediated by a green brand image. This provides input to green product producers, especially in the beauty care industry, that green brand image is necessary and crucial to attract consumers 'attention to increase potential consumers' green purchase intention.
\end{abstract}

Keywords: green product, green brand image, green purchase intention

\begin{abstract}
Abstrak
Penelitian dilakukan untuk mengidentifikasi pengaruh produk hijau dan citra merek hijau terhadap minat beli produk hijau pada produk kecantikan. Isu lingkungan hidup disertai berbagai kampanye dan instruksi pemerintah dalam pengelolaan kerusakan lingkungan hidup mendorong preferensi konsumen dan produsen untuk mengkonsumsi dan memproduksi produk berkonsep ramah lingkungan. Keterbatasan penelitian dan kontradiksi dari penelitian sebelumnya mendorong penulis untuk mengetahui pengaruh produk hijau, citra merek hijau dan minat beli produk hijau dalam tren pemasaran hijau yang sedang berkembang di Indonesia saat ini. Data yang digunakan adalah data primer dengan kuesioner yang dikumpulkan dari 120 responden di Jabodetabek. Teknik pengambilan sampel menggunakan metode non probability sampling dengan teknik purposive sampling yang kriteria sampel adalah perempuan berusia mulai dari 18 tahun, mengetahui dan menyukai produk perawatan kecantikan yang berhubungan dengan produk hijau. Hasil penelitian menunjukkan bahwa produk hijau dan citra merek hijau akan bersama-sama mempengaruhi minat beli produk hijau dalam upaya pemasaran hijau. Sementara itu, hubungan antara produk hijau dan minat beli produk hijau perlu dimediasi oleh citra merek hijau. Hal ini memberikan masukan kepada produsen produk hijau khususnya pada industri perawatan kecantikan bahwa citra merek hijau menjadi hal yang penting dan krusial untuk menarik perhatian konsumen dalam rangka meningkatkan minat beli calon konsumen terhadap produk hijau.
\end{abstract}

Kata kunci : produk hijau, citra merek hijau, minat beli produk hijau

\section{Pendahuluan}

Isu kerusakan lingkungan hidup sudah menjadi kecemasan dunia sejak abad ke-19. Perhatian dunia mengenai lingkungan hidup pertama kali dituangkan di dalam Konferensi Stockholm pada tahun 1972, dilanjutkan di Rio de Janeiro tahun 1992 dan kemudian di Johannesburg tahun 2002. Berbagai kampanye 
penyelamatan lingkungan hidup menumbuhkan kecemasan masyarakat akan akibat dari sikap konsumtif yang bertentangan dengan upaya keberlanjutan lingkungan. Hal ini menyebabkan fenomena dimana preferensi konsumen menjadi lebih tertarik dengan produk lebih ramah lingkungan. Minat konsumen terhadap produk ramah lingkungan dan tuntutan dari kebijakan pemerintah menjadi tantangan sekaligus tren peluang baru bagi para pelaku bisnis. Mereka meresponnya dengan menciptakan strategi baru berkonsep ramah lingkungan yang diterapkan pada produk atau proses bisnis perusahaannya. Adapun produk yang mempunyai karakteristik ramah lingkungan tersebut dapat juga disebut dengan istilah produk hijau. Konsep produk hijau ini sekaligus dapat memberikan nilai tambah pada citra merek perusahaan dan membantu posisi persaingan perusahaan di dunia bisnis masa kini. Sejumlah merek produk hijau mengklaim produk mereka sebagai produk bebas bahan kimia berbahaya, paraben-free, cruelty-free, vegan-friendly ataupun memiliki kemasan berbahan daur ulang dan dapat didaur ulang. Karakteristik produk tersebut sangat erat kaitannya dengan konsep ramah lingkungan pada produk hijau yang menjadi topik penelitian saat ini.

Penawaran produk hijau di Indonesia

tidak hanya menuai sikap positif dari masyarakat, namun juga menimbulkan pandangan kritis terhadap kualitas produk hijau sekaligus kredibilitas produsennya. Oleh karena hal tersebut pembangunan pemasaran hijau sudah banyak mencuri perhatian dunia penelitian dengan berbagai aspek-aspek yang diduga dapat mendorong perhatian konsumen untuk membeli produk hijau. Untuk itu, ecolabel dan nilai produk hijau memberikan kontribusi pengaruh terbesar terhadap minat beli konsumen hijau di Sabah (Kong et al., 2014). Penelitian sejenis memberikan hasil bahwa produk hijau berpengaruh positif dan siginifikan terhadap minat beli konsumen akan produk hijau (Hernizar et al., 2020). Sementara itu, Rahbar dan Wahid (2011), citra merek disebut sebagai salah satu elemen penting yang mempengaruhi minat beli produk hijau. Namun disebutkan juga dalam penelitian ini bahwa penelitian citra merek dalam minat beli produk hijau belum banyak ditemukan (Joshi \&
Rahman, 2015). Sementara itu, Narula \& Desore (2016) menyimpulkan bahwa ke depannya akan bermanfaat bagi komunikasi pemasaran jika mengeksplorasi lebih lanjut salah satunya upaya pencitraan merek hijau Hasil penelitian Dewanti et al. (2018) menyatakan bahwa citra merek hijau berpengaruh signifikan terhadap minat beli produk hijau Di sisi lain penelitian oleh Singh (2014) menunjukkan tidak adanya pengaruh dari citra merek hijau terhadap minat beli produk hijau dan kemudian didukung dengan penelitian dari Rakhmawati et al. (2019) yang juga menunjukkan bahwa citra merek hijau yang diciptakan tidak cukup mempengaruhi konsumen untuk membeli. Berdasarkan dari penjelasan atas keterbatasan penelitian sebelumnya dan juga ditemukannya kontradiksi penelitian di Indonesia perihal pengaruh produk hijau dan citra merek hijau terhadap minat beli produk hijau, maka penulis tertarik untuk meneliti lebih lanjut pengaruh kedua variabel tersebut terhadap minat beli produk hijau pada tren industri perawatan kecantikan saat ini. Hasil penelitian akan bermanfaat untuk menentukan pemusatan kosentrasi dalam upaya perusahaan mengembangkan pemasaran hijau.

\section{Produk Hijau}

Produk hijau atau produk ramah lingkungan merupakan produk yang dirancang dan diproses untuk mengurangi efek-efek yang dapat mencemari lingkungan, baik dalam produksi, pendistribusian, dan pengonsumsinya (Makatumpias et al., 2018). Sementara itu, D'Souza et.al (2006) mendefinisikan produk hijau sebagai produk yang memiliki manfaat bagi konsumen serta manfaat sosial yang dirasakan oleh konsumen, seperti tidak memberikan dampak buruk bagi lingkungan. Berdasarkan pengertian tersebut, maka dapat disimpulkan bahwa produk hijau merupakan produk yang didesain, diproduksi, dikemas dan dipasarkan dengan konsep ramah lingkungan sebagai upaya meninggalkan dampak sekecilkecilnya terhadap lingkungan sekaligus memberikan manfaat dan nilai tambah produk kepada konsumennya.

Penelitian Suparna et al. (2018) dalam penelitiannya menjelaskan kriteria di dalam produk hijau adalah sebagai berikut: 
1. Persepsi produk

Produk adalah produk hijau atau produk ramah lingkungan yang tidak berbahaya terhadap hewan dan lingkungan.

2. Kemasan

Kemasan produk dapat menyajikan elemen tertentu dan terlihat adanya keterkaitan dengan kepedulian terhadap lingkungan.

3. Komposisi isi

Komposisi merupakan bahan daur ulang yang dapat menyatakan pemakaian pada batas tertentu dan mengklaim pemakaian secara keseluruhan pada tingkat atau jumlah yang lebih rendah, serta menimbulkan kerusakan minimum terhadap lingkungan.

\section{Citra Merek Hijau}

Menurut Grant (2008), merek hijau didefinisikan sebagai merek yang menawarkan nilai tambah ramah lingkungan secara signifikan daripada para pesaingnya dan mampu menarik perhatian konsumen yang menetapkan prioritas tinggi dalam pembelian produk ramah lingkungan. Sementara itu, merek hijau mencakup serangkaian atribut dan manfaat terkait dengan berkurangnya dampak lingkungan yang merugikan dan penciptaan kesan positif pada konsumen dengan membangun kepedulian lingkungan mereka (Mohd Suki, 2016). Lebih lanjut, citra merek hijau didefinisikan sebagai keseluruhan rangkaian tayangan, konsepsi, dan kekhawatiran terhadap suatu merek di dalam pikiran pelanggan yang berkorelasi dengan masalah ramah lingkungan dan keberlanjutan (Doszhanov \& Ahmad, 2015). Berdasarkan pemahaman tersebut maka dapat dikatakan citra merek hijau sebagai sebuah desain perusahaan yang mengungkapkan informasi mereknya dan membentuk keyakinan serta kesan ramah lingkungan di benak konsumen yang melihat atau menggunakan merek tersebut.

Menurut Chen et al. (2017) citra merek hijau memiliki 5 konstruksi sebagai berikut ini :

1. Merek dianggap sebagai patokan komitmen lingkungan.

2. Reputasi lingkungan dari merek luar biasa.

3. Performa lingkungan atas merek dikatakan sukses.
4. Pencitraan merek didasarkan pada penekanannya terhadap perlindungan lingkungan.

5. Komitmen lingkungan merek dapat dipercaya.

\section{Minat Beli Produk Hijau}

Minat beli didefinisikan sebagai kekuatan pendorong atau motif intrinsik yang mampu mendorong seseorang untuk menaruh perhatian secara spontan, wajar, mudah, tanpa paksaan dan selektif pada suatu produk untuk kemudian mengambil keputusan membeli (Kartikasari et al., 2018). Sementara itu, Chen \& Chang (2012) mendefinisikan minat beli produk hijau sebagai suatu kemungkinan seorang konsumen akan membeli produk tertentu dikarenakan kebutuhan ramah lingkungannya. Dikutip dari penelitian Chen \& Chang (2012), Pavlou (2003) dan Chang, Chen (2008) mengatakan untuk mengukur minat beli produk hijau meliputi tiga hal sebagai berikut :

1. Anda bermaksud membeli produk ini karena kepedulian terhadap lingkungan dari produk ini.

2. Anda berharap untuk membeli produk ini di masa depan karena pelaksanaan ramah lingkungannya.

3. Secara keseluruhan, Anda senang membeli produk ini karena merupakan produk ramah lingkungan.

\section{Hipotesis Penelitian}

Berdasarkan uraian pada penelitianpenelitian terdahulu, maka hipotesis yang dirumuskan pada penelitian ini adalah sebagai berikut:

H1: Produk hijau secara positif akan berpengaruh terhadap citra merek hijau.

H2: Produk hijau secara positif akan berpengaruh terhadap minat beli produk hijau.

H3: Citra merek hijau secara positif akan berpengaruh terhadap minat beli produk hijau.

H4: Produk Hijau berpengaruh terhadap minat beli produk hijau melalui citra merek hijau.

\section{Metode Penelitian}

Pada penelitian ini, penulis mengumpulkan lima merek kecantikan hijau 
yang paling umum ditemukan di dalam beberapa artikel bertopik green beauty ataupun clean beauty. Merek yang terpilih adalah The Body Shop, Oriflame, Innisfree, Love Beauty and Planet dan Sukin. Berdasarkan pra survey penulis terhadap 30 responden, diketahui bahwa dari kelima merek tersebut responden lebih mengenal The Body Shop sebesar 63,3\%, Oriflame 23,3\% dan Innisfree $13,3 \%$, sedangkan dua merek lainnya tidak menjadi perhatian responden. Berdasarkan hasil pra survey ini, penulis menetapkan dua merek yaitu The Body Shop dan Oriflame untuk menjadi contoh yang relevan pada alat penelitian selanjutnya (kuesioner).

Studi penelitian menggunakan desain penelitian asosiatif dengan hubungan kausal. Jenis data merupakan data kualitatif yang dikuantitatifkan dan diperoleh dari data primer dengan penyebaran kuesioner. Kuesioner dikumpulkan dari 120 responden dengan pembobotan menggunakan skala likert. Wilayah populasi penelitian ditentukan berdasarkan area penyebaran toko offline terbanyak, dalam hal ini adalah The Body Shop. Wilayah yang tercatat paling banyak adalah Jabodetabek dengan total 36 toko yang tersebar di seluruh wilayahnya (The Body Shop, 2021). Teknik pengambilan sampel menggunakan metode non probability sampling dengan teknik purposive sampling, dimana kriteria sampel adalah perempuan berusia mulai dari 18 tahun, mengetahui dan menyukai produk perawatan kecantikan yang berhubungan dengan produk hijau. Analisa hubungan langsung dan tidak langsung antar variabel menggunakan analisis jalur dimana produk hijau sebagai variabel bebas, citra merek hijau sebagai variabel antara dan minat beli produk hijau sebagai variabel terikatnya.

\section{Hasil dan Pembahasan}

1. Karakteristik Responden

Tabel 1 Karakteristik Responden

\begin{tabular}{|c|c|c|c|}
\hline \multirow{2}{*}{$\begin{array}{c}\text { No } \\
1\end{array}$} & \multicolumn{2}{|c|}{ Karakteristik Responden } & \multirow{2}{*}{$\begin{array}{l}\% \\
28\end{array}$} \\
\hline & Usia & 18 - 25 tahun & \\
\hline & & $>25$ tahun & 72 \\
\hline \multirow[t]{2}{*}{2} & $\begin{array}{l}\text { Pendidikan } \\
\text { Terakhir }\end{array}$ & SMA/SMK & 18 \\
\hline & & Perguruan Tinggi & 82 \\
\hline \multirow[t]{4}{*}{3} & Pekerjaan & Mahasiswa & 9 \\
\hline & & Ibu Rumah Tangga & 27 \\
\hline & & Karyawan & 53 \\
\hline & & Lain-Lain & 11 \\
\hline \multirow[t]{6}{*}{4} & Domisili & Jakarta & 33 \\
\hline & & Bogor & 6 \\
\hline & & Depok & 2 \\
\hline & & Tangerang & 14 \\
\hline & & Bekasi & 42 \\
\hline & & Lain-Lain & 3 \\
\hline
\end{tabular}

2. Uji Instrumen Penelitian

Hasil uji validitas seluruh variabel $X, Z$ dan $Y$ adalah $>0,361$. Oleh karena hal tersebut maka dapat disimpulkan bahwa seluruh pernyataan kuesioner dari variabel $X$ (produk hijau), $Z$ (citra merek hijau) dan $Y$ (minat beli produk hijau) dinyatakan valid dan dapat digunakan pada pengujian selanjutnya.

Hasil uji reliabilitas menunjukkan nilai cronbach's alpha dari variabel $X \quad(8$ pernyataan), $Z$ (14 pernyataan) dan $Y$ (9 pernyataan) adalah $>0,7$. Oleh karena hal tersebut maka dapat disimpulkan bahwa seluruh pernyataan dari variabel $X$ (produk hijau), Z (citra merek hijau) dan Y (minat beli produk hijau) dinyatakan reliabel dan dapat diandalkan. 
3. Hasil Uji Asumsi Klasik

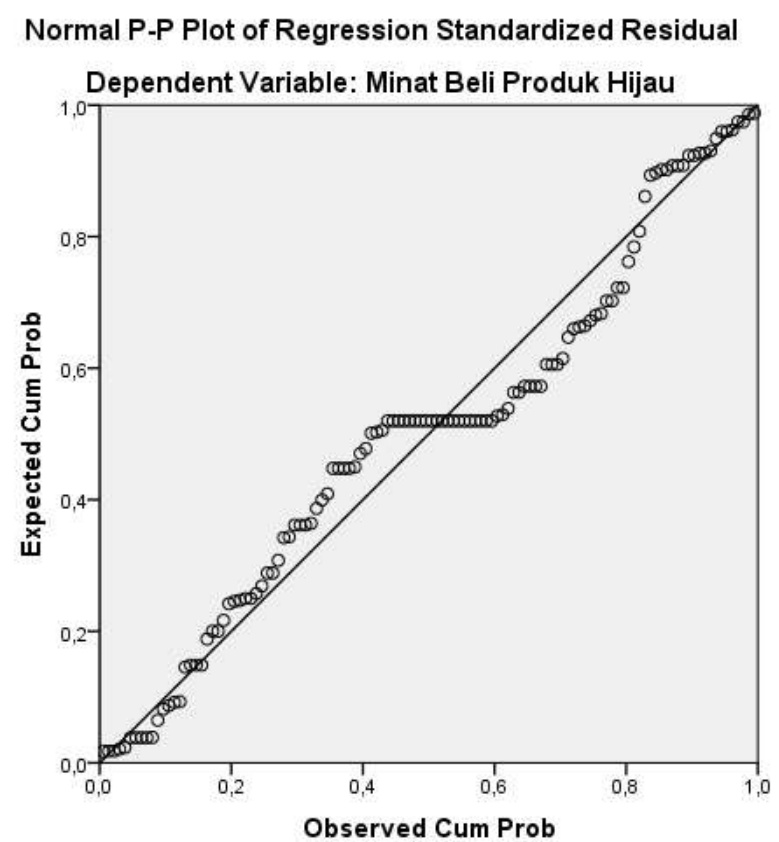

Gambar 1

Hasil Uji Normalitas Grafik Normal Plot

Gambar 1 di atas menunjukkan bahwa hasil uji normalitas dari grafik normal plot yaitu data menyebar disekitar garis diagonalnya yang dapat dikatakan bahwa data penelitian terdistribusi normal.

Hasil uji multikolinearitas nilai VIF sebesar $1,602<10$ dan nilai Tolerance sebesar 0,624>0,10 yang dapat diartikan bahwa antara variabel independen yaitu produk hijau dan citra merek hijau tidak terjadi gejala multikolinearitas.

Hasil uji heteroskedastisitas menggunakan uji glejser dari variabel $X$ (produk hijau) sebesar 0,361 > 0,05 dan dari variabel Z (citra merek hijau) sebesar 0,340 > 0,05 . Hasil uji ini menyatakan pada model regresi penelitian ini tidak terjadi gejala heteroskedastisitas.

\section{Hasil Uji Analisis Jalur (Path Analysis)}

Hasil uji analisis jalur pengaruh produk hijau dan citra merek hijau terhadap minat beli produk hijau dan pengaruh produk hijau terhadap minat beli produk hijau melalui citra merek hijau ditampilkan dalam gambar berikut:

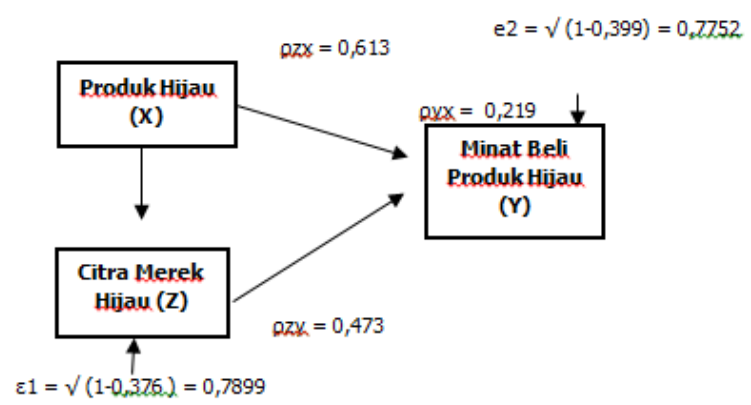

Gambar 2

Analisis Jalur Model Gabungan

Hasil perhitungan pengaruh langsung dan tidak langsung produk hijau terhadap minat beli produk hijau melalui citra merek hijau ditampikan dalam tabel berikut:

Tabel 2

Hasil Perhitungan Pengaruh

\begin{tabular}{lccc}
\hline Variabel & $\begin{array}{c}\text { Pengaruh } \\
\text { Langsung }\end{array}$ & $\begin{array}{c}\text { Pengaruh } \\
\text { Tidak } \\
\text { Langsung }\end{array}$ & $\begin{array}{c}\text { Total } \\
\text { Pengaruh }\end{array}$ \\
\hline $\mathrm{X} \rightarrow Z$ & 0,613 & & 0,613 \\
$\mathrm{X} \rightarrow \mathrm{Y}$ & 0,219 & & 0,219 \\
$\mathrm{Z} \rightarrow \mathrm{Y}$ & 0,473 & & 0,473 \\
$\mathrm{X} \rightarrow \mathrm{Z} \rightarrow \mathrm{Y}$ & 0,219 & 0,290 & 0,509 \\
\hline
\end{tabular}

5. Hasil Uji Hipotesis

Hasil uji analisis jalur pengaruh produk hijau dan citra merek hijau terhadap minat beli

1. Hasil Uji Parsial dengan t-test

Hasil uji hipotesis dengan menggunakan t-test ditampikan dalam tabel berikut:

Tabel 3

Hasil Perhitungan Uji Parsial dengan t-test

\begin{tabular}{ccccrc}
\hline $\begin{array}{c}\text { N } \\
\mathbf{0}\end{array}$ & Hipotesis & Sig & Beta & $\begin{array}{c}\text { t } \\
\text { hitung }\end{array}$ & $\begin{array}{c}\text { Keteranga } \\
\mathbf{n}\end{array}$ \\
\hline 1 & $\mathrm{H} 1(\mathrm{X} \rightarrow \mathrm{Z})$ & 0,00 & 0,61 & 8,43 & diterima \\
2 & $\mathrm{H} 2(\mathrm{X} \rightarrow \mathrm{Y})$ & 0,02 & 0,22 & 2,42 & diterima \\
3 & $\mathrm{H} 3(\mathrm{Z} \rightarrow \mathrm{Y})$ & 0,00 & 0,47 & 5,21 & diterima \\
\hline
\end{tabular}

$\mathrm{t}$ tabel $=\mathrm{t}(0,025 ; 118)$

$\mathrm{t}$ tabel $=1,984$

2. Hasil Uji Simultan dengan F-test

Hasil uji hipotesis simultan dengan F-test menunjukkan bahwa signifikansi $\mathrm{X}$ dan $\mathrm{Z}$ 
secara simultan terhadap $\mathrm{Y}$ sebesar $0,000<$ 0,05 dan nilai $F$ hitung 38,806 > 3,92, sehingga dapat disimpulkan produk hijau dan citra merek hijau secara simultan berpengaruh terhadap minat beli produk hijau.

\section{Hasil Uji Koefisien Determinasi}

Hasil uji koefisien determinasi produk hijau dan citra merek hijau terhadap minat beli produk hijau adalah sebagai berikut:

Tabel 5

Hasil Perhitungan R Square

\begin{tabular}{|ccccc|}
\hline \multicolumn{4}{|c|}{ Model Summary } \\
\hline Model & $\mathrm{R}$ & $\begin{array}{c}\mathrm{R} \\
\text { Square }\end{array}$ & $\begin{array}{c}\text { Adjusted } \\
\text { R Square }\end{array}$ & $\begin{array}{c}\text { Std. Error } \\
\text { of the } \\
\text { Estimate }\end{array}$ \\
\hline 1 &, $632^{\mathrm{a}}$ & 0,399 & 0,389 & 3,292 \\
\hline
\end{tabular}

a. Predictors: (Constant), Citra Merek Hijau, Produk Hijau

Uji koefisien determinasi adalah sebesar 0,399 , sehingga minat beli produk hijau dapat dijelaskan oleh variabel produk hijau dan citra merek hijau sebesar 39,9\%, dan sisanya $60,1 \%$ dijelaskan oleh variable lain yang tidak diteliti pada penelitian ini.

\section{Pengaruh produk hijau (X) terhadap citra merek hijau (Z)}

Hasil penelitian berdasarkan data responden perempuan dimana sebagian besar karyawan berusia di atas 25 tahun dan berlatar belakang pendidikan terakhir perguruan tinggi menunjukan bahwa produk hijau berpengaruh positif terhadap citra merek hijau. Oleh karena hal tersebut, dapat disimpulkan bahwa sebagian besar responden dengan karakter yang sudah subjektif dan kritis terhadap perilaku konsumtifnya mempunyai kecenderungan memperhatikan pengaruh variabel produk hijau terhadap citra merek hijau produk perawatan kecantikan yang menjadi studi penelitian kali ini. Hasil penelitian ini mendukung penelitian Johannes et al. (2015), sehingga dapat dikatakan bahwa citra merek sebuah produk atau perusahaan dapat dikembangkan lebih baik melalui pengaruh produk hijaunya sendiri baik berdasarkan hasil penelitian pada industri minuman maupun perawatan kecantikan.

\section{Pengaruh produk hijau (X) terhadap minat beli produk hijau (Y)}

Hasil penelitian berdasarkan data responden perempuan dimana sebagian besar karyawan berusia di atas 25 tahun dan berlatar belakang pendidikan terakhir perguruan tinggi menunjukan bahwa produk hijau berpengaruh positif secara langsung terhadap minat beli produk hijau. Oleh karena hal tersebut, dapat disimpulkan bahwa sebagian besar responden dengan karakter yang sudah subjektif dan kritis terhadap perilaku konsumtifnya mempunyai kecenderungan memperhatikan variabel produk hijau yang akan mempengaruhi minat beli produk hijau mereka. Hasil penelitian ini mendukung penelitian Kong et al. (2014) dan Hernizar et al. (2020), sehingga dapat dikatakan bahwa produk hijau secara langsung dapat mempengaruhi minat beli produk hijau konsumen baik dari sektor industri produk hijau secara umum (Kong et al.), industri minuman (Hernizar et al.) dan juga industri perawatan kecantikan.

\section{Pengaruh citra merek hijau (Z) terhadap minat beli produk hijau (Y)}

Hasil penelitian berdasarkan data responden perempuan dimana sebagian besar karyawan berusia di atas 25 tahun dan berlatar belakang pendidikan terakhir perguruan tinggi menunjukan bahwa citra merek hijau berpengaruh positif dan signifikan terhadap minat beli produk hijau. Oleh karena hal tersebut, dapat disimpulkan bahwa sebagian besar responden dengan karakter yang sudah subjektif dan kritis terhadap perilaku konsumtifnya mempunyai kecenderungan mementingkan variabel citra merek hijau yang nantinya akan mempengaruhi pemikiran mereka dalam keinginan membeli produk hijau.

Hasil penelitian ini berlawanan dengan penelitian Singh (2014), dimana masih terdapat celah asumsi yaitu jika penelitian dengan merek hijau elektronik tidak mempengaruhi minat beli produk hijau konsumen, namun jika merek hijau tersebut adalah merek perawatan kecantikan maka akan lebih mempengaruhi minat beli produk hijau konsumen. Hasil penelitian ini mendukung penelitian dari Dewanti et al. 
(2018), dimana hasil penelitian mereka juga mengungkapkan bahwa citra merek hijau berpengaruh secara signifikan terhadap minat beli produk hijau pada industri perawatan kecantikan yang sejenis. Selain itu, hasil penelitian ini tidak sejalan dengan penelitian dari Rakhmawati et al. (2019), dimana studi penelitian tersebut menjelaskan bahwa karakter responden adalah pengguna The Body Shop 3 sampai dengan 6 tahun dan responden terdiri dari $78,7 \%$ perempuan sedangkan sisanya laki-laki. Sedangkan pada penelitian ini responden adalah 100\% perempuan yang tidak diharuskan pernah menggunakan merek yang dicontohkan. Dari kedua hubungan analisis kedua penelitian ini maka dapat dikatakan citra merek hijau tetap mempunyai pengaruh baik signifikan dari sudut pandang calon pelanggan maupun kurang signifikan dari sudut pandang pelanggan terhadap minat beli produk hijau.

\section{Pengaruh produk hijau (X) terhadap minat beli produk hijau (Y) melalui citra merek hijau (Z)}

Hasil penelitian berdasarkan data responden perempuan dimana sebagian besar karyawan berusia di atas 25 tahun dan berlatar belakang pendidikan terakhir perguruan tinggi menunjukan bahwa produk hijau berpengaruh positif secara lebih kuat terhadap minat beli produk hijau dengan dimediasi oleh citra merek hijau. Oleh karena hal tersebut, dapat disimpulkan bahwa sebagian besar responden dengan karakter yang sudah subjektif dan kritis terhadap perilaku konsumtifnya mempunyai kecenderungan akan lebih terpengaruh minat belinya jika suatu produk hijau diikuti dengan gambaran citra merek yang baik. Hasil penelitian ini telah menjawab pertanyaan penulis dan membuktikan hipotesis penulis bahwa hubungan antara produk hijau terhadap minat beli produk hijau akan menjadi lebih kuat dengan dibantu oleh mediasi citra merek hijau khususnya pada industri perawatan kecantikan.

\section{Kesimpulan}

Berdasarkan hasil penelitian dan pembahasan maka kesimpulan dari penelitian dapat dijelaskan sebagai berikut :
1. Produk hijau berpengaruh positif secara langsung terhadap citra merek hijau. Hal ini menunjukan produk hijau mempunyai peranan penting dan perlu diperhatikan oleh pemasar hijau dalam upaya meningkatkan citra merek hijau produk atau perusahaannya.

2. Citra merek hijau juga berpengaruh positif secara langsung terhadap minat beli produk hijau. Hal ini menunjukkan secara khusus citra merek hijau suatu produk atau perusahaan mampu mempengaruhi minat beli produk hijau konsumen.

3. Produk hijau berpengaruh positif secara langsung dan tidak langsung terhadap minat beli produk hijau. Hal ini menunjukkan bahwa produk hijau akan ikut mempengaruhi minat beli produk hijau konsumen baik secara langsung maupun tidak langsung sehingga pengaruh produk hijau tetap harus menjadi perhatian bagi pemasar produk hijau dalam meningkatkan penjualan produk hijaunya.

4. Pengaruh secara tidak langsung produk hijau terhadap minat beli produk hijau dan total pengaruh produk hijau terhadap minat beli produk hijau melalui citra merek hijau lebih besar daripada pengaruh langsungnya produk hijau terhadap minat beli produk hijau. Hal ini menunjukkan bahwa pemasar produk hijau perlu berkonsentrasi pada peningkatan citra merek hijau mereka sebagai mediasi peningkatan minat beli produk hijau dalam upaya pemasaran mereka.

\section{Daftar Pustaka}

Chen, Y. S., \& Chang, C. H. (2012). Enhance green purchase intentions: The roles of green perceived value, green perceived risk, and green trust. Management Decision, 50(3), 502-520. https://doi.org/10.1108/002517412112 16250

Chen, Y. S., Hung, S. T., Wang, T. Y., Huang, A. F., \& Liao, Y. W. (2017). The influence of excessive product packaging on green brand attachment: The mediation roles of green brand attitude and green brand image. Sustainability (Switzerland), 9(4). https://doi.org/10.3390/su9040654 
Dewanti, T. R., Suharyono, \& Bafadhal, A. S. (2018). Pengaruh green brand image terhadap green trust serta implikasinya terhadap green purchase intention (survei online pada calon konsumen lush fresh handmade cosmetic di indonesia). Jurnal Administrasi Bisnis, 62(1), 1-9. administrasibisnis.studentjournal.ub.ac.i d

Doszhanov, A., \& Ahmad, Z. A. (2015). Customers' intention to use green products: the impact of green brand dimensions and green perceived value. SHS Web of Conferences, 18(2012), 01008.

https://doi.org/10.1051/shsconf/201518 01008

Hernizar, A. T., Ramdan, A. M., \& Mulia, F. (2020). Pengaruh green product dan green brand awareness terhadap green purchase intention. E-Jurnal Ekonomi Dan Bisnis Universitas Udayana, 3, 263. https://doi.org/10.24843/eeb.2020.v09. i03.p03

Johannes, Suswita, R., \& Ilunitedra. (2015). Pengaruh Green Produk Terhadap Brand Image Produk Air Minum Dalam Kemasan Merek Aqua (The Effect of Green Product on Brand Image of Aqua PackagedWater Drinking). Digest Marketing, 1(1), 41-48. https://doi.org/ISSN: 2302-4682

Joshi, Y., \& Rahman, Z. (2015). Factors affecting green purchase behaviour and future research directions. International Strategic Management Review, 3(1-2), 128-143.

https://doi.org/10.1016/j.ism.2015.04.0 01

Kartikasari, M. D., Dimyati, M., \& Sukarno, H. (2018). Pengaruh green marketing dan pengetahuan terhadap keputusan pembelian dengan mediasi minat membeli konsumen sariayu martha tilaar di kota jember. Journal Ekonomi Dan Akuntansi, V(2), 172-177. https://doi.org/ISSN : 2355-4665

Kong, W., Harun, A., Sulong, R. S., \& Jaratin, L. (2014). The influence of consumers ' perception of green products. Asian Social Science, 4(8), 924-939.
https://doi.org/ISSN(e):

22244441/ISSN(p): 2226-5139

Makatumpias, D., Moniharapon, S., \& Tawas, H. N. (2018). Pengaruh green product dan brand image terhadap keputusan the effect of green product and brand image on the purchase decision. Fakultas Ekonomi Dan Bisnis, Jurusan Manajemen Universitas Sam Ratulangi Manado, 6(4), 4063-4072.

Mohd Suki, N. (2016). Green product purchase intention: impact of green brands, attitude, and knowledge. British Food Journal, 118(12), 2893-2910. https://doi.org/10.1108/BFJ-06-20160295

Narula, S. A., \& Desore, A. (2016). Framing green consumer behaviour research: Opportunities and challenges. Social Responsibility Journal, 12(1), 1-22. https://doi.org/10.1108/SRJ-08-20140112

Rakhmawati, D., Puspaningrum, A., \& Hadiwidjojo, D. (2019). Hubungan green percieved value, green brand image, dan green trust terhadap green purchase intention. IQTISHODUNA, 15(1), 1-12. https://doi.org/P-ISSN: 1829-524X,E-ISSN:2614-3437

Singh, K. P. (2014). Managing green purchase intention: a theoretical framework. 3(11), 409-416. https://doi.org/ISSN: 2278-0181

Suparna, G., Ekawati, N. W., Suasana, I. G. A. K. G., \& Sriathi, A. A. A. (2018). Menciptakan Green Brand Personality Bagi Merek Ramah Lingkungan. Matrik: Jurnal Manajemen, Strategi Bisnis Dan Kewirausahaan, $1,153$. https://doi.org/10.24843/matrik:jmbk.2 018.v12.i02.p07

The Body Shop. (2021). The body shop store locator. Www.Thebodyshop.Co.Id. https://www.thebodyshop.co.id/storeloc ator 